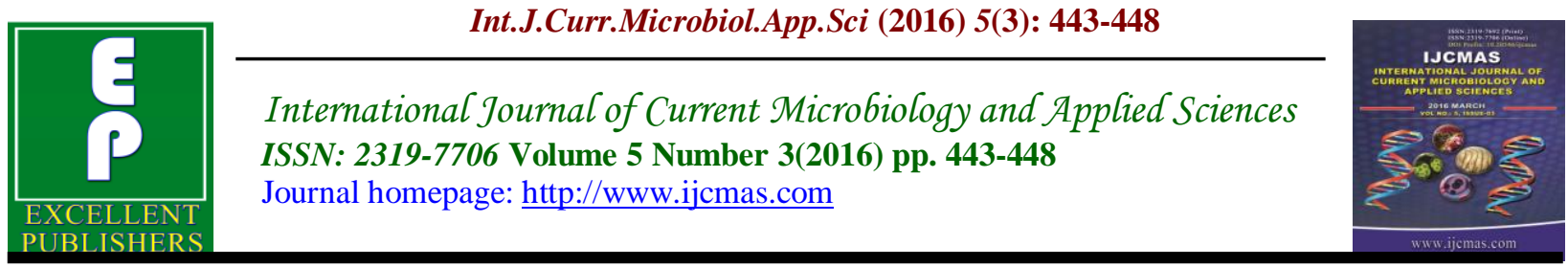

Original Research Article

http://dx.doi.org/10.20546/ijcmas.2016.503.051

\title{
Invitro Evaluation of Chemical Formulates on Xanthomonas axonopodis pv. punicae
}

\author{
B. V. Thirumalesh ${ }^{1 *}$, B. Thippeswamy ${ }^{2}$ and M. Krishnappa ${ }^{1}$ \\ ${ }^{1}$ Department of Applied Botany, Bioscience Block, Kuvempu University, Jnana Sahyadri, \\ Shankaraghatta-577 451, Shimoga (Dist.), Karnataka, India \\ ${ }^{2}$ Department of Microbiology, Bioscience Block, Kuvempu University, Jnana Sahyadri, \\ Shankaraghatta-577 451, Shimoga (Dist.), Karnataka, India \\ *Corresponding author
}

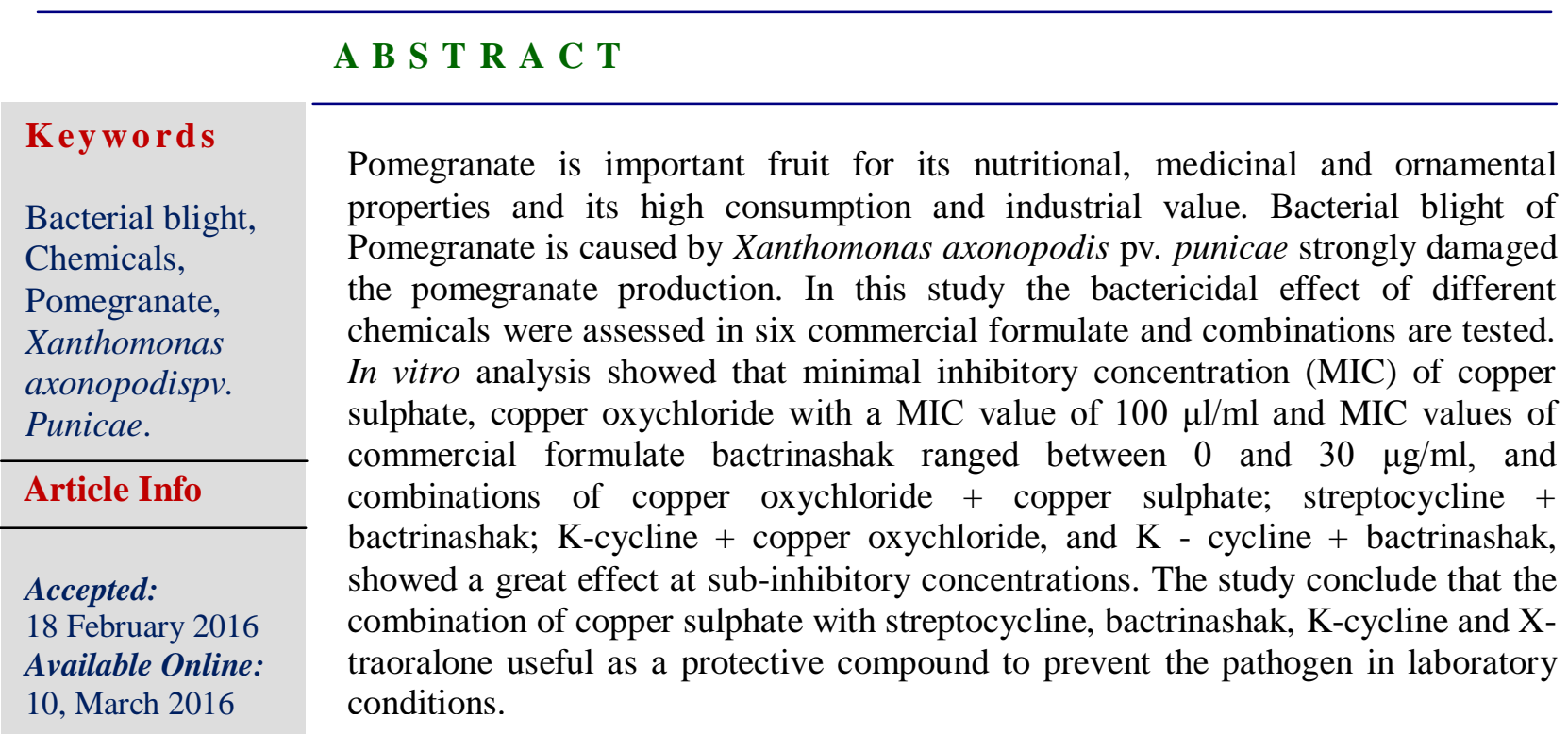

\section{Introduction}

Pomegranate (Punica granatum), being a favourite table fruit of tropical and subtropical regions of the world, has emerged as commercial fruit in many Indian states including Maharashtra, Andhra Pradesh, Uttar Pradesh, Gujarat, Rajasthan, Karnataka and Tamil Nadu (Mondal and Mani, 2009). Bacterial diseases cause substantial loss to the productivity of major crop plants. Unlike fungal diseases, bacterial diseases not controleffectively through chemical methods (Mondal and Shanmugam, 2013). However, bacterial blight caused by Xanthomonas axonopodis pv. punicae (Xap) strongly damaged the pomegranate production, inducing large economic losses to the Indian growers (Mondal and Sharma 2009).The disease was of minor importance until the recent appearance of the Xap in epidemic form in 
many pomegranate growing states of India, including Karnataka and Maharashtra. The bacterial blight of pomegranate is known to be confined mainly in India (Chand and Kishun, 1991).Several management options have been investigated. Among them application of antibiotics, chemicals and other cultural practices. Treatments by chemicals had limited success against the disease (Kumar, et al. 2009). Bacterial blight is one of the most devastating diseases of pomegranate occurring in major pomegranate growing states of India. Bacterial blight has been observed damaging the pomegranate crop in moderate to severe proportion resulting in enormous losses. The infected plant parts are the potential sources of primary inoculums to spread the disease. Attempts have been made in India to control this disease by either uprooting the whole plant or spraying chemicals/antibiotics (Manjula and Khan, 2002), but complete control has not been achieved so far. Studies on Xap chemical control are different variable results. With respect to standard bactericides, secondary infection spread of the pathogen in the field can only be reduced by treating seedlings with streptocycline and copper compounds. The aim of this study was to screen in vitro a range of antimicrobial agents and their effect against Xap; in laboratory conditions.

\section{Materials and Methods}

\section{Bacterial Cultures, Media and Growth Conditions}

\section{Isolation and Identification of Xap}

Bacterial blight infected leaves and fruits (Fig.1) were collected from the pomegranate fields of Challakere Taluk, Chitradurga District, Karnataka, India. The infected leaf were cut into $2-3 \mathrm{~cm}$ pieces and sterilized by $70 \%$ ethanol for $30 \mathrm{~min}$ followed by 2-3 times distilled water wash. Then they were squeezed with fine forceps to release the pathogenic extracts and then the crude extracts were directly cultured on nutrient agar and Glucose yeast chalk agar(GYCA) (Petersen, 2010) plates with $1 \% \mathrm{NaCl}$ and kept for incubation at $28^{\circ} \mathrm{C}$ for 24 to 72 hour. After incubation the yellow colour colonies were isolated. Identification and characterization of the bacterial blight pathogen was carried out by subjecting to various biochemical tests, such as Gram staining, potassium hydroxide $(\mathrm{KOH})$ solubility test, Kovac's oxidase test, starch hydrolysis, Lipase activity and Arginine dehydrogenase test (Lelliot and Stead, 1987), gelatin hydrolysis, and catalase tests. Three strains of Xap were used: Banjagere3(BAN-3), Challakere-1(CLK- 1), and Nayakanahatty-3(NYH- 3) strains were selected and cultured for further analysis.

\section{In vitro Conditions}

Six commercial formulates was evaluated against three strains of Xap (BAN-3, CLK1, and NYH-3). The antimicrobial substances used were copper sulphate, copper oxychloride, streptocycline, bactrinashak, K- cyclineandX-tra. The MIC and $\mathrm{MBC}$ were determined by the broth macrodilution method (Peterson and Shanholtzer, 1992) in $2 \mathrm{ml}$ of GYCA. For copper sulphate, copper oxychloride, streptocycline, bactrinashak, K- cycline and $\mathrm{X}$-tra concentrations were prepared at 1,3 , $5,8,10,12,15,20,40,60$ and 100, 150, 250 and $400 \mu \mathrm{l} / \mathrm{ml}$ concentrations, for controls double distilled sterile water used.

The starting bacterial inoculum was 1$5 \times 10^{6} \mathrm{cfu} \mathrm{ml}^{-1}$, and bacterial populations were monitored at $0,24,48$ and $72 \mathrm{~h}$ by cfu counts on GYCA broths. The MIC and $\mathrm{MBC}$ of compound at which growth after 24 to $48 \mathrm{~h}$ of incubation at $28^{0} \mathrm{C}$, and subinhibitory concentrations assayed in combinations for their antibacterial effect. 


\section{Results and Discussion}

\section{Isolation and Identification of Xap}

The isolated yellow colour colonies were identified and characterized of the bacterial blight pathogen by various biochemical tests, such as Gram staining, potassium hydroxide $(\mathrm{KOH})$ solubility test, Kovac's oxidase test, starch hydrolysis, Lipase activity and Arginine dehydrogenase test (Lelliot and Stead, 1987), gelatin hydrolysis, and catalase tests and pathological tests. The obtained results were compared with authentic Xanthomonas results.

\section{Sensitivity Effect on Xap Growth}

The six chemical compounds MIC and MBC values of tested are listed in Table 1. All compounds inhibited bacterial growth after 24 hours incubation, all formulates were copper sulphate and copper oxychloride 100 $\mu \mathrm{g} / \mathrm{ml}$, Streptocycline, bactrinashak, KCyclineand X-tra $20 \mu \mathrm{l} / \mathrm{ml}$.

The MBC values below 2xMIC for copper sulphate, copper oxychloride, streptocycline, bactrinashak, K- Cycline and X-tra, addition of these compounds at MIC values produced reduction in growth of bacterial cultures after $24 \mathrm{~h}$ of incubation, The mixed compounds was evaluated in combinations at sub-inhibitory concentrations $(1 / 2 \mathrm{x}$ MIC), the following combinations compared separately: copper oxychloride + copper sulphate; streptocycline + bactrinashak; KCycline + copper oxychloride,K- Cycline + $\mathrm{X}$-traand $\mathrm{K}$ - Cycline + bactrinashak. For those combinations, sub inhibitory concentrations of each component drastically reduced cfu counts from the initial inoculum (Table 2 and fig-2) and distilled water served as control.

In the present study, field survey was undertaken in the major pomegranate growing region of Chitradurga district, challakere taluk and the study revealed that the bacterial blight disease prevails in up to $90.0 \%$ orchards. Bacterial blight of pomegranate was found to be highly destructive, wide spread disease and a threat to pomegranate production due to its high epidemic potential. The antibacterial compounds are spraying in controlling bacterial diseases. The commercial bactericides control under in vitro six chemical treatments showed effective response to each isolate. Combination of streptocycline (100-300 ppm) with copper oxychloride $(0.3 \%)$ was reported to be effective against $X$. citri (Kale et al., 1994). Desai et al. (1967) and Raj and Moniz (1967) had reported effectiveness of streptocycline against Xanthomonas sp. Bacillus subtilis were considerably reduced in the field by the application of the antagonist (Okigbo and Osuinde, 2003), differences in disease control according to the inoculation method (Hausbeck et al. 2000) reported that streptomycin applied to seedlings inoculated by misting increased their survival after transplant and prevented severe disease symptoms from developing in the field, Streptocycline was best in control (Mishra and Prakash, 1992).

Acibenzolar-S-methyl is a systemic inducer of resistance in plants (Kessmann et al., 1994). Application of acibenzolar-S-methyl reduced the incidence of diseases caused by different pathogens such as bacterial diseases (Brisset et al., 2000). Rego et al. (2006) obtained similar in vitro results when these two methods were used to evaluate fungicides to control $C$. liriodendri. Some of the fungicides used in our experiments were also previously evaluated in vitro by Halleen et al. (2007). In vitro inhibition of Grampositive bacteria has also been reported (Hinton and Ingram, 2003). 
Table.1 Effect of Chemical Compounds against Three Strains of $X$. axanopodis pv. punicae

\begin{tabular}{|c|c|c|c|c|}
\hline \multirow[t]{3}{*}{ SI.No. } & \multirow{3}{*}{$\begin{array}{l}\text { Chemical compounds / } \\
\text { antibiotics }\end{array}$} & \multicolumn{3}{|c|}{ Strains of $X$. axanopodis pv. punicae ${ }^{a}$} \\
\hline & & BAN-3 & CLK-2 & NYH-3 \\
\hline & & MIC/MBC & MIC/MBC & MIC/MBC \\
\hline 1 & Control & $0 / 0$ & $0 / 0$ & $0 / 0$ \\
\hline 2 & Copper sulphate & $100 />200$ & $100 />200$ & $100 />200$ \\
\hline 3 & Copper oxychloride & $100 />200$ & $100 />200$ & $100 />200$ \\
\hline 4 & Streptocycline & $20 / 40$ & $20 / 40$ & $20 / 40$ \\
\hline 5 & Bactrinashak & $20 / 40$ & $20 / 40$ & $20 / 40$ \\
\hline 6 & K- cycline & $20 / 40$ & $20 / 40$ & $20 / 40$ \\
\hline 7 & $X-\operatorname{tra}$ & $20 / 40$ & $20 / 40$ & $20 / 40$ \\
\hline
\end{tabular}

${ }^{\mathrm{a}} \mathrm{MIC}$ and $\mathrm{MBC}$ are expressed in $\mu \mathrm{l} / \mathrm{ml}$

Table2 In vitro Synergistic Effect on Xap, after 24 h of Incubation

\begin{tabular}{|c|c|c|c|}
\hline Sl.No. & $\begin{array}{l}\text { Initial inoculums } \\
\left(\mathrm{cfu} \mathbf{~ m}^{-1}\right)^{\mathrm{a}}\end{array}$ & $\begin{array}{l}\text { Combination of chemical } \\
\text { compounds }\end{array}$ & $\begin{array}{l}\text { Recovered cells } \\
\left(\text { cfu } \mathbf{~ m l}^{-1}\right)^{\mathrm{a}}\end{array}$ \\
\hline 1 & \multirow{11}{*}{$1.12 \pm 0.0 \times 10^{6}$} & $1 / 2$ Copper oxychloride $(50 \mu \mathrm{l} / \mathrm{ml})$ & $6.32 \pm 2.01 \times 10^{9}$ \\
\hline 2 & & $1 / 2$ Copper sulphate $(50 \mu \mathrm{l} / \mathrm{ml})$ & $6.71 \pm 1.72 \times 10^{9}$ \\
\hline 3 & & $\begin{array}{l}1 / 2 \text { Copper oxychloride }+1 / 2 \text { Copper } \\
\text { sulphate }\end{array}$ & $5.13 \pm 0.92 \times 10^{2}$ \\
\hline 4 & & $1 / 2$ Streptocycline $(10 \mu \mathrm{l} / \mathrm{ml})$ & $4.68 \pm 1.02 \times 10^{9}$ \\
\hline 5 & & 1/2 Bactrinashak $(10 \mu \mathrm{l} / \mathrm{ml})$ & $5.20 \pm 6.81 \times 10^{9}$ \\
\hline 6 & & $1 / 2$ Streptocycline $+1 / 2$ Bactrinashak & $3.45 \pm 2.61 \times 10$ \\
\hline 7 & & $1 / 2 \mathrm{~K}$ - cycline $(10 \mu \mathrm{l} / \mathrm{ml})$ & $6.48 \pm 2.02 \times 10^{9}$ \\
\hline 8 & & $1 / 2 \mathrm{~K}$ - cycline $+1 / 2$ Copper oxychloride & $6.48 \pm 7.58 \times 10^{9}$ \\
\hline 9 & & $1 / 2 \mathrm{X}-\operatorname{tra}(10 \mu \mathrm{l} / \mathrm{ml})$ & $7.48 \pm 2.60 \times 10^{9}$ \\
\hline 10 & & $1 / 2 \mathrm{~K}$ - cycline $+1 / 2 \mathrm{X}$-tra & $7.42 \pm 2.02 \times 10^{9}$ \\
\hline 11 & & $1 / 2 \mathrm{~K}$ - cycline+ $1 / 2$ Bactrinashak & $4.28 \pm 6.85 \times 10^{9}$ \\
\hline
\end{tabular}

${ }^{\mathrm{a}}$ values presented are means $( \pm \mathrm{SE})$ for four repetitions

Fig.1 Bacterial Blight on Pomegranate Fruits

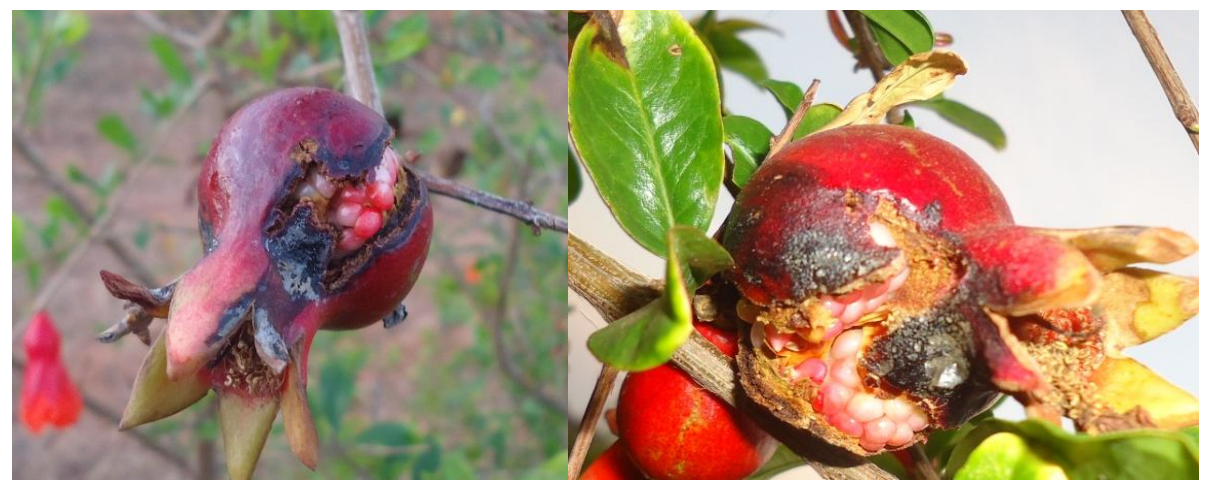


Fig.2 In vitro Synergistic Effect on Xap, after $24 \mathrm{~h}$ of Incubation

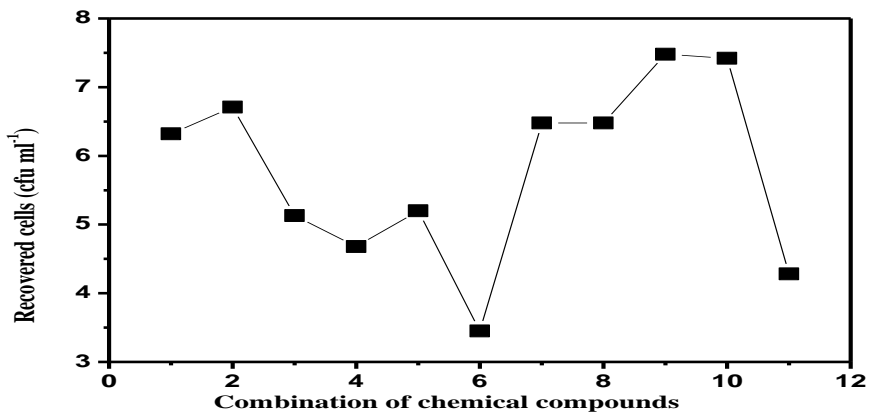

Our study revealed that copper sulphate and copper oxychloride combined with streptocycline, bactrinashak, $\mathrm{K}$ - cycline and $\mathrm{X}$-tra and alone were the most effective treatments in inhibiting the Xap. Products containing copper has reported to significantly reduced, fruit spotting produced by this pathogen (Gleason et al., 1993). Copper treatments were more active when mixed with other, such enhanced activity has also been reported on Pseudomonas syringaepv. Mango when copper is combined with carbamate fungicides. Relevant data from this study was synergistic effects of streptocycline +copper sulphate against Xap. Both compounds combinations of at half concentration gives significantly reduced bacteria than copper sulphate alone or streptocycline or bactrinashak, K-cycline and X-traalone. Using of copper applications to crops lead to contamination in soil, it pollutes soil environment (Ninot et al., 2002), and copper tolerance of plantpathogenic bacteria increased (Andersen $e t$ al., 1991). Consequently, copper applications on commercial crops should be reduced (Ninot et al., 2002). Our results show that copper sulphate and copper oxychloride at reduced dosages in combination with streptocycline, bactrinashak, K-cycline and X-traor alone proved useful as a protective compound to prevent the blight.

\section{References}

Brisset, M.N., Cesbron, S., Thomson, S.V., Paulin, J.P. 2000. Acibenzolar- Smethyl induces the accumulation of defense-related enzymes in apple and protects from fire blight. Eur. J. Plant Pathol., 106: 529-536.

Chand, R., Kishun, R. 1991. Studies on bacterial blight of pomegranate. Indian Phytopathol. 44: 370-372.

Desai, S.G., Patel, M.K., Desai, M.V. 1967. In vitro activity of streptocycline against bacterial plant pathogen. Indian Phytopathol., 20: 296-300.

Gleason, M.L., Gitaitis, R.D., Ricker, M.D. 1993. Recent progress in understanding and controlling bacterial canker of tomato in eastern North America. Plant Dis., 77: 1069- 1076.

Halleen, F., Fourie, P.H., Crous, P.W. 2007. Control of black foot disease in grapevine nurseries. Plant Pathol., 56: 637-645.

Hausbeck, M.K., Bell, J., Medina-Mora, C.M., Podolsky, R., Fulbright, D.W. 2000. Effect of bactericides on population sizes and spread of Clavibacter michiganensis subsp. michiganensis on tomatoes in the greenhouse and on disease development and crop yield in the field. Phytopathol., 90: 38-44.

Hinton, A., Ingram, K.D. 2003. Bactericidal 
activity of tripotassium phosphate and potassium oleate on the native flora of poultry skin. Food Microbiol., 20: 405-410.

Kale, K.B., Kolte, S.O., Peshney, N.L. 1994. Economics of chemical control of citrus canker caused by Xanthomonas compestris pv. citri under field conditions. Indian Phytopathol., 47: 253-255.

Kessmann, H., Staub, T., Hofmann, C., Maetzke, T., Herzog, J. 1994. Induction of systemic acquired disease resistance in plant by chemicals. Annu. Rev. Phytopathol., 32: 439-459.

Kumar, R, Jahagirdar S.M.R., Yenjerappa, S.T., Patil, H.B. 2009. Epidemiology and management of bacterial blight of pomegranate caused by Xanthomonas axonopodispv. punicae. Acta. Hortic., 818: 291-296.

Lelliot, R., Stead, D.E. 1987. Methods for the diagnosis of bacterial disease of plants, Methods in plant pathology. Preece T.F (Eds). Blackwell Scientific Publication. 2: 216.

Manjula, C.P., Khan, A.N.A. 2002. Incidence of bacterial blight of pomegranate (Punica granatum L.) in Karnataka. In: Paper Presented at the Annu. Meet. Symp. Plant Disease Scenario in Southern India, Held at Bangalore (India) on December 19-21.

Mishra, A.K., Prakash, O. 1992. Bacterial canker of mango: incidence and control. Ind phytopath., 45: 172-175.

Mondal, K.K., Sharma, J. 2009. Bacterial blight: an emerging threat to pomegranate export. Ind. Farm., 59:
$22-23$.

Mondal, K.K., Shanmugam, V. 2013. Advancements in the diagnosis of bacterial plant pathogens: An overview, Biotech. Mol. Biol. Rev., 8: $1-11$.

Ninot, A., Aleta, N., Moragrega, C., Montesinos, E. 2002. Evaluation of a reduced copper spraying program to control bacterial blight of walnut. Plant Dis., 86: 583-587.

Okigbo, N.R., Osuinde, I.M. 2003. Fungal leaf spot diseases of mango (Mangifera indica L.) in southeastern Nigeria and biological control with Bacillus subtilis. Plant Protect. Sci., 39: 70-77.

Petersen, Y., Mansvelt, E.L., Venter, E., Langenhoven, W.E. 2010. Detection of Xanthomonas axonopodis pv. punicae causing bacterial blight on pomegranate in South Africa. Aust. Plant Pathol., 39: 544-546.

Peterson, L.R., Shanholtzer, C.J. 1992. Test for bactericidal effects of antimicrobial agents: technical performance and clinical relevance. Clin. Microbiol. Rev., 5: 420-432.

Raj, H., Moniz, L. 1967. Bioassay of antibiotics and fungicides with Xanthomonas oryzae as a test organism. Indian Phytopathol., 20: 315-317.

Rego, C., Farropas, L., Nascimento, T., Cabral, A., Oliveira, H. 2006. Black foot of grapevine: sensitivity of Cylindrocarpon destructans to fungicides. Phytopathol. Mediterr., 45: S93-S100.

\section{How to cite this article:}

Thirumalesh, B.V., Thippeswamy, B. and Krishnappa, M. 2016. Invitro Evaluation of Chemical Formulates on Xanthomonas axonopodis pv. Punicae. Int.J.Curr.Microbiol.App.Sci. 5(3): 443448. doi: http://dx.doi.org/10.20546/ijcmas.2016.503.051 